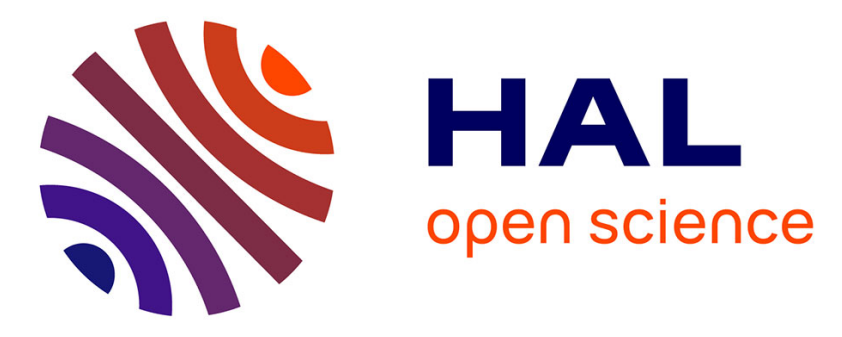

\title{
Recently identified microbial guild mediates soil N2O sink capacity
}

Christopher Jones, Aymé Spor, Fiona Brennan, Marie-Christine Breuil, David Bru, Philippe Lemanceau, Bryan Griffiths, Sara Hallin, Laurent Philippot

\section{- To cite this version:}

Christopher Jones, Aymé Spor, Fiona Brennan, Marie-Christine Breuil, David Bru, et al.. Recently identified microbial guild mediates soil N2O sink capacity. 20. European Nitrogen Cycle Meeting, ENC2015 Conference, University of Aberdeen. GBR., Sep 2015, Aberdeen, United Kingdom. 65 p. hal-02744179

\author{
HAL Id: hal-02744179 \\ https://hal.inrae.fr/hal-02744179
}

Submitted on 3 Jun 2020

HAL is a multi-disciplinary open access archive for the deposit and dissemination of scientific research documents, whether they are published or not. The documents may come from teaching and research institutions in France or abroad, or from public or private research centers.
L'archive ouverte pluridisciplinaire HAL, est destinée au dépôt et à la diffusion de documents scientifiques de niveau recherche, publiés ou non, émanant des établissements d'enseignement et de recherche français ou étrangers, des laboratoires publics ou privés. 
ORAL PRESENTATIONS 


\title{
11. Recently identified microbial guild mediates soil $\mathrm{N}_{2} \mathrm{O}$ sink capacity
}

\author{
Laurent Philippot ${ }^{1}$, Christopher M. Jones ${ }^{1,2}$, Aymé Spor ${ }^{1}$, Fiona P. Brennan ${ }^{1,3,4}$, \\ Marie-Christine Breuil ${ }^{1}$, David Bru ${ }^{1}$, Philippe Lemanceau ${ }^{1}$, Bryan Griffiths ${ }^{3,5}$, Sara \\ Hallin², Laurent Philippot ${ }^{1}$ \\ ${ }^{1}$ INRA, UMR 1347 Agroécologie, F-21065 Dijon cedex, France \\ ${ }^{2}$ Department of Microbiology, Swedish University of Agricultural Sciences, Uppsala, Sweden \\ ${ }^{3}$ Teagasc, Environmental Research Center, Wexford, Ireland \\ ${ }^{4}$ Ecological Sciences Group, The James Hutton Institute, Scotland \\ ${ }^{5}$ Crop and Soil Systems Research Group, SRUC, Edinburgh, Scotland \\ laurent.philippot@dijon.inra.fr
}

Nitrous oxide is the predominant ozone-depleting substance and contributes approximately 6 per cent to overall global warming. Terrestrial ecosystems account for nearly 70 per cent of total global $\mathrm{N}_{2} \mathrm{O}$ atmospheric loading, of which at least 45 per cent can be attributed to microbial cycling of nitrogen in agriculture. The reduction of $\mathrm{N}_{2} \mathrm{O}$ to nitrogen gas by microorganisms is critical for mitigating its emissions from terrestrial ecosystems, yet the determinants of a soil s capacity to act as a source or sink for $\mathrm{N}_{2} \mathrm{O}$ remain uncertain. To address whether the composition and structure of the $\mathrm{N}_{2} \mathrm{O}$ reducing communities matters for $\mathrm{N}_{2} \mathrm{O}$ consumption in soil, we analyzed the diversity of this guild amongst the different European soils by pyrosequencing. We demonstrated using

structural equation modeling that the soil $\mathrm{N}_{2} \mathrm{O}$ sink capacity is mostly explained by the abundance and phylogenetic diversity of a newly described $\mathrm{N}_{2} \mathrm{O}$ reducing microbial group, which mediate the influence of edaphic factors. Analyses of interactions and niche preference similarities suggest niche differentiation or even competitive interactions between organisms with the two types of $\mathrm{N}_{2} \mathrm{O}$ reductase. Using co-occurrence analysis, we further identified several recurring communities comprised of co occurring $\mathrm{N}_{2} \mathrm{O}$ reducing bacterial genotypes that were significant indicators of the soil $\mathrm{N}_{2} \mathrm{O}$ sink capacity across different European soils. 